\title{
FGFR Gene Rearrangement
}

National Cancer Institute

\section{Source}

National Cancer Institute. FGFR Gene Rearrangement. NCI Thesaurus. Code C153240.

A molecular abnormality indicating rearrang ement of an FGFR family gene. 